Revista Iberoamericana, Vol. LXXVI, Núm. 232-233, Julio-Diciembre 2010, 807-819

\title{
NATURALEZA, HISTORIA Y NEOCOLONIALISMO EN CUBAGUA, DE ENRIQUE BERNARDO NÚÑEZ
}

\author{
POR \\ AlejandRo BRUzuAL \\ Universidad de Pittsburgh
}

Quisieron hacer una ciudad de piedra y apenas levantaron unas ruinas.

Cubagua

Es la iniciación de una lucha que no ha terminado aún, que no puede terminar.

Cubagua

Si consideramos que Cubagua (1931), la tercera novela del escritor y periodista venezolano Enrique Bernardo Núñez (1895-1964), pueda ser entendida como la obra clave del vanguardismo en Venezuela, no deja de sorprender el que, hasta hoy, haya sido tan poco conocida y estudiada. ${ }^{1}$ Su "prosa castigada" - como la calificó Uslar Pietri (1948:147)-, su hermetismo difícilmente descifrable, la coexistencia del vanguardismo de su concepción formal con evidencias de marcas modernistas, escasamente explican su exclusión del canon literario continental. ${ }^{2}$ En realidad, es un texto que podría inscribirse en los debates poscoloniales latinoamericanos, en cuanto trabaja las relaciones entre historia y Estado, ofreciendo una visión literaria peculiar de los orígenes de la hegemonía económica y cultural continental. La trama se ubica en los primeros años de la Conquista, en la pequeña isla que le da título a la novela, y en paralelo con la tercera década del siglo xx, momento central para la dictadura (1908-1935) de Juan Vicente Gómez, cuando se verifica un fuerte viraje modernizador en la sociedad venezolana.

Desde una perspectiva historiográfica de la narrativa nacional, la publicación de Cubagua a inicios de los treinta se ubica entre Doña Bárbara (1929), la obra emblemática

1 No obstante recibiera una notable bienvenida del medio literario nacional, la recepción de la obra del autor no pasó de reseñas periodísticas hasta cuarenta años más tarde, cuando Larrazábal Henríquez (1969) y Orlando Araujo (1972) le dedicaron estudios de cierta envergadura.

2 El autor fue visto en su momento más como cronista que como novelista, y su novela considerada más como "documento" que como creación literaria. De hecho, a más de setenta y cinco años de editada por primera vez, inclusive con reediciones posteriores en editoriales de relevancia, como Casa de las Américas (1978) y Biblioteca Ayacucho (1987), todavía no conoce traducción alguna a otro idioma. 
de Rómulo Gallegos, y Las lanzas coloradas (1931) de Arturo Uslar Pietri. Si bien estos dos libros difieren notablemente en estilo y contenido, ofrecen propuestas que pueden leerse como anticipos de los proyectos posgomecistas que buscaban reordenar la nación, ya desde principios de los años treinta. Si bien -como ha sido analizado entre otros por John Beverley (1987)-, Doña Bárbara anuncia una incipiente oposición civil, ${ }^{3}$ que delinea el proyecto populista que llevaría a la presidencia al mismo Gallegos en 1947, ${ }^{4}$ detrás de la renovación "futurista" de Las lanzas coloradas se evidencia la posibilidad de un reacomodo reformista y democratizador de las mismas fuerzas del gomecismo, al cual Uslar Pietri estaba vinculado. Entre ambas, Cubagua aporta un extraño oráculo literario y político que, en muchos sentidos, negaba ambas propuestas. ${ }^{5}$

Cubagua no fue un tour de force en la obra de Núñez, como han sugerido algunos de sus críticos, ni una suerte de generación espontánea de la narrativa venezolana. Fue, más bien, el resultado de una reflexión crítica sobre la historia del país, en su contexto internacional, que llevó a Núñez a asumir una evidente postura antimperialista. La breve novela se puede pensar como una fragua conceptual, que tiene antecedentes y consecuencias relevantes en el resto de su obra, ${ }^{6}$ junto a la cual constituye un proyecto literario al que se le suman algunos de sus ensayos, ${ }^{7}$ textos biográficos y crónicas posteriores. En este trabajo vamos a analizar algunas ideas sobre tiempo y nación en Cubagua, desarrollando las conexiones que se dan en su entramado formal entre historia, Estado y producción, así como aprovecharemos para hacer algunas reflexiones cruzadas con las otras novelas ya mencionadas, Doña Bárbara y Las lanzas coloradas.

La trama de Cubagua puede resumirse en pocas palabras. ${ }^{8}$ A mediados de los años veinte, el ingeniero de minas Ramón Leiziaga llega a Margarita (isla mayor de

3 La historiografía tradicional toma los sucesos de 1928 como origen de esta oposición. En los eventos de la llamada "Semana del estudiante" aparecen, por primera vez, los nombres de los políticos más conocidos de lo que será el posgomecistas, entre otros, Rómulo Betancourt, Raúl Leoni, Rafael Caldera, Jóvito Villalba.

4 Rómulo Betancourt escribe un artículo, tan temprano como en 1930, en Repertorio Americano, donde señala la identidad de su generación con la "que personifica a Santos Luzardo" (202).

5 Vilanova explica que "la novela superaba ampliamente lo que hoy se denomina "horizonte de la expectativa', no sólo del lector contemporáneo, sino también el de los novelistas latinoamericanos y el de los críticos en general [...]" (234).

6 Particularmente, Sol interior (1918) y Después de Ayacucho (1920), como también sus tres cuentos escritos desde 1923, pero publicado en 1932 como Don Pablos en América. Luego sería seguido por La galera de Tiberio, escrita entre 1931 y 1932, y publicada por primera vez en 1938, edición que fue destruida por el mismo autor.

7 Núñez, en sus mejores ensayos (sobre Raleigh y El Dorado, por ejemplo), se mueve con libertad del orden de la cultura referencial (historia y literatura) al de la ficción, como Jorge Luis Borges, logrando un entre-lugar sorprendentemente eficaz.

8 En vida del autor se realizaron cuatro ediciones de Cubagua: 1931, 1935, 1947 y 1959. Núñez dejó numerosas correcciones a estas ediciones y en su propio manuscrito, que han sido sólo en parte dilucidadas e incorporadas en las ediciones póstumas. Utilizamos en este trabajo la publicada por Biblioteca Ayacucho, incluida en Novelas y ensayos.

Revista Iberoamericana, Vol. LXXVI, Núms. 232-233 Julio-Diciembre 2010, 807-819 ISSN 0034-9631 (Impreso) $\quad$ ISSN 2154-4794 (Electrónico) 
Venezuela), enviado por el gobierno central a supervisar los recursos minerales de la zona. Poco después, al visitar las ruinas de la capital de la vecina isla de Cubagua, sin que se llegue a saber si se trata de ilusión, alucinación o realidad, Leiziaga participa en un areito, un rito indígena en el cual se conecta con la historia, con sus diversos momentos y personajes. Paralelamente al viaje del protagonista, son desarrollados breves pasajes que tratan la esclavitud de los indígenas y la explotación de los placeres de perlas. A continuación, el ingeniero interfiere en una pesca ilegal de perlas, haciendo valer su condición de funcionario público. Más allá de una suerte de pulsión de vieja explotación colonial y de moderna corrupción burocrática, el personaje se siente confundido por una suerte de identificación simbólica entre las perlas y Nila Cálice, la mujer de la cual se ha enamorado, y quiere hacer suya a través de la posesión de las perlas. Como consecuencia, Leiziaga es hecho preso a su vuelta a Margarita. En uno de los dos finales que se conocen -y que aceptamos al mismo tiempo, como posibilidades coherentes de la obra-, el protagonista escapa de la cárcel y se interna en el Orinoco, mientras que en la variante que pareciera ser la última decisión del autor, Leiziaga retorna a Cubagua.

La novela presenta personajes secundarios, agrupados en dos grandes grupos. El primero, los que pueden ser vistos como de una sola realidad, seres planos y de un solo rostro, pertenecientes a una decrépita clase media. A través de ellos, se tiene una idea de las condiciones de vida y las características de la hegemonía social en la Venezuela de principios de siglo. Son los representantes de diversos espacios profesionales: el juez Leonidas Figueiras, el secretario de gobierno Benito Arias, el coronel Juan de la Cruz Rojas, el médico rural Gregorio Almozas, el propietario de la cantina Jesús Quijada, y a quienes se les suman los administradores norteamericanos Henry Stakelun y Joseph Jhonston (sic), gerentes de la explotación mineral de la isla, y agentes de la expansión del capital extranjero en el país.

El segundo grupo es el que forman personajes con nombres que anuncian activas traslaciones temporales y biográficas. ${ }^{9}$ El fraile franciscano español Dionisio de la Soledad representa la mediación entre la sociedad indígena y la occidental, planteadas en una equivalencia cultural y hasta con una perspectiva de coexistencia sin asimetrías. De allí que sea visto con sorpresa por Leiziaga: “-¡Un religioso en prácticas de hechicería! En Nueva Cádiz la prisión perpetua, el in pace" (43). Fray Dionisio es la figura del traductor de conocimientos bidireccionales, testigo que permanece, es el que ve y puede

9 Estas traslaciones son de sangre y de bando ideológico, mas no de clase. En efecto, situaciones y personajes similares se encuentran en sus novelas anteriores, lo que parece decir que Núñez no explora la permeabilidad social producida por las guerras desde los mismos inicios coloniales. Podríamos decir que esta movilidad también se verificó en el proyecto populista posgomecista a través de la corrupción. En las novelas de Núnez hay enriquecimiento, pero no subida o conciliación de clases. En Sol interior se desarrolla la imposibilidad del amor entre personajes de clases diversas, Armando Ibáñez y Marta Federman, mientras que, de manera más evidente, en Después de Ayacucho se enfatizan las diferencias sociales de Miguel Franco y Teresa Montenegro.

\begin{tabular}{l} 
Revista Iberoamericana, Vol. LXXVI, Núms. 232-233 Julio-Diciembre 2010, $807-819$ \\
\hline ISSN 0034-9631 (Impreso)
\end{tabular} 
narrar: "comenzó a hablar confusamente del pasado, de las cosas exteriores y de sus relaciones con lo que ha sido y es hace trescientos, hace miles de años" (23). Como la más compleja construcción literaria de la trama, es él mismo y otro a la vez, con rasgos del Bartolomé de las Casas (quien, sin embargo, era dominico) a la vez que de los viajeros coloniales Humboldt, Bonpland y Depons. Posee su propia cabeza momificada, y ha vivido ininterrumpidamente desde los comienzos de la Conquista. Es él el catalizador de los diversos conceptos del tiempo representados. En cuanto al personaje femenino principal, Nila Cálice es descrita desde distintos puntos de vista ubicados en otros personajes de la novela, funcionando todos al mismo tiempo, que el lector se ve obligado a aceptar como coexistentes y yuxtapuestos. Puntos de vista que, inclusive, no siempre son coincidentes en una función en muchos sentidos rashomoniana, aunque siempre como símbolo de rebeldía. Puede ser una indígena moderna transculturizada, que ha estudiado en Princeton, y a la vez, una arquera, hija del cacique tamanaco Rimarima, quien se rebela contra los conquistadores. También puede ser ella hija de un comerciante leproso del siglo xx, Pedro Cálice, quien a su vez es también un traficante de esclavos del siglo XVI. El resto de los personajes tienen funciones menores en la trama, hombres de la zona que repiten los nombres de los conquistadores españoles: Antonio Cedeño, Miguel Ocampo y Teófilo Ortega. Ellos son el pueblo, una categoría cambiante en la obra, que no ofrece posibilidad de resolución a la mezcla de sangre y que siempre esta en movimiento, que cobra unidad en su referencia a la tierra, al paisaje, a la naturaleza que los envuelve. En estos personajes priva más el rol que ocupan en un momento determinado, que las "razas", pues en ellos habitan "almas superpuestas, vigilantes para que ninguna cobre imperio sobre la otra" (59).

Un par de capítulos son dedicados a la vida cotidiana de la Cubagua-isla, durante los primeros días de la Colonia, poco antes de la invasión de la isla por indígenas de tierra firme, hecho que provoca una violenta venganza de los colonos españoles. Aquí se presentan los dos personajes indígenas más relevantes del relato, el héroe Arimuy, hijo del cacique Toronaima, que se sumará luego a piratas franceses para seguir luchando contra los españoles, y Cuciú, una india prostituida por los españoles que, cuando va a ser asesinada en la hoguera, un adivino de su tribu la convierte en garza roja. Aquí se describe también las acciones del conde milanés Luis de Lampugnano, un personaje construido en espejo del protagonista Leiziaga, ${ }^{10}$ por medio de la superposición de

${ }^{10}$ La genealogía de Leiziaga fija antecesores en los conquistadores, por una parte -un soldado que participó en la muerte por traición de Guaicaipuro-, y, por otra, en vascos vinculados a la Compañía Guipuzcoana, contra la cual insurgen los blancos criollos para producir el movimiento independentista venezolano. Es decir, la combinación Lampugnano-Leiziaga es la senda de la explotación colonial fracasada. Esta constitución genealógica de permanencias hegemónicas se puede encontrar en las dos primeras novelas de Núñez, siempre en una suerte de línea única, referencial. Es Guillermo Federman, descendiente de buscadores de El Dorado, compañeros de los Welser, en Sol interior, y también el Gaspar Montenegro, de origen encomendero, ya noble en la península, en Después de Ayacucho.

Revista Iberoamericana, Vol. LXXVI, Núms. 232-233 Julio-Diciembre 2010, $807-819$
ISSN 0034-9631 (Impreso) 
características y acciones equivalentes. Ambos buscan infructuosamente enriquecerse en Cubagua. ${ }^{11}$ Lampugnano es un aventurero italiano, cuya existencia y presencia en la isla está plenamente documentada por cronistas de la época, a principios del siglo XVI. ${ }^{12}$ Finalmente, en capítulo aparte, la novela también incluye al dios Vocchi, hermano de la deidad caribe Amalivaca. En Vocchi el autor cruza la cultura del Orinoco con la de las antiguas culturas de la India y Mesopotamia, emparentando el momento inmemorial del diluvio universal con el de los primeros días de la conquista americana.

Como a primera vista puede intuirse por la constitución de sus personajes, esta breve y fragmentaria novela pone en funcionamiento un complejo mecanismo temporal que indaga en las relaciones entre historia y nación. De la sencillez del mismo título se desprenden los elementos principales del juego narrativo. Primero, la isla caribeña como espacio geográfico que, en efecto, proyecta la realidad integral del continente todo (Miliani xliii). Segundo, el vínculo temporal que en su título subyace hace referencia a relaciones entre el período inicial de la conquista, en su estadio insular, y el momento mismo de la escritura de la novela, a finales de los años veinte. Y, por último, en su referencia histórica, Cubagua asocia la violenta expoliación conquistadora de los recursos perlíferos - dinámica que condujo a su excesivamente rápido agotamiento a la par que al exterminio de los nativos esclavizados-, con el comienzo de la explotación petrolera a gran escala durante la dictadura de Gómez, bajo las condiciones impuestas por las empresas internacionales, particularmente las norteamericanas. ${ }^{13}$ Estos tres elementos cifrados en su título -lugar, tiempo y explotación- conforman una alegoría sobre la persistencia colonizadora, basada en la reactuación de su propio fracaso como proyecto no sustentable.

Hay que hacer énfasis aquí en su peculiar constitución como novela histórica, lo que ha sido visto como un esfuerzo distinto a las obras precedentes, al menos en Venezuela, en cuanto cumple "una función crítica, revulsiva, cuestionadora, reconstructiva [...] la productividad de la ficción como alternativa válida de acercamiento a la comprensión crítica del pasado histórico" (Pacheco 42). Sin embargo, no vemos el texto como una

11 Leiziaga es un anti-héroe similar al Miguel Franco de Después de Ayacucho, no obstante su tono paródico, que había sido antecedido por el personajes picaresco del cuento "Don Pablos en América" (escrito durante los años los veinte, y terminado en 1928). Luis Britto García ha señalado ya a Leiziaga como pícaro (649).

12 Una hermosa descripción de este personaje, a la que parece ajustarse Núñez, se encuentra en Benzoni (117-8).

13 En Cubagua se dio, además, el primer antecedente de la producción petrolera venezolana, como indica de paso la novela. Los indígenas lo recogían como aceite con finalidades curativas, y como tal fue enviado por primera vez a Europa. En el otro extremo cronológico, no se debe olvidar que Estados Unidos apoyó (en 1908) el desplazamiento del incómodo dictador nacionalista Cipriano Castro por su segundo y también dictador, Juan Vicente Gómez, quien pagaría con concesiones petroleras este apoyo que duró 27 años.

Revista Iberoamericana, Vol. LXXVI, Núms. 232-233 Julio-Diciembre 2010, $807-819$
ISSN 0034-9631 (Impreso) 
mera reconstrucción del pasado, sino más bien como una tensa radicalización de las relaciones entre pasado y presente. Cubagua se vale del mito y de la crónica histórica para su construcción estética, así como para su crítica de la historia. En todo caso, como afirma Miliani: "No es distorsión de la historia con sentido clasista dominante, sino intrahistoria, revelación poética de las verdades escamoteadas por la historia grande, verdad subyacente, convertida: vertida con arte" (xxv-xxvi).

Se podría pensar, incluso, que lo que hace Núñez es invertir el acercamiento esperado entre ficción y realidad, en referencia a cómo se relaciona al pasado y al presente. En efecto, la referencia a la Venezuela gomecista queda textualizada como el hecho novelesco, ficción propiamente dicha, mientras que el autor da muestras de una enfática voluntad de serle fiel al relato histórico. En este sentido puede ser visto como una evasión doble. Por un lado, hablando de "lo que fue", evitaba la confrontación con el orden vigilado de la dictadura. Por otro, ateniéndose en lo posible a un archivo amplio (que suma a la "historia" otros múltiples fragmentos textuales) ${ }^{14}$ se aparta de tentaciones reaccionarias a monumentalizar ese mismo pasado a través del recurso estético, ese pasado "definitivamente muerto", como dirá con posterioridad el mismo autor [ver infra].

A diferencia de Las lanzas coloradas o de su propia Después de Ayacucho (1920), ${ }^{15}$ que ficcionalizan sus historias referenciales -bandos en guerra y clases sociales enfrentadas - en una discusión ideológica de tono metafórico dirigido a la comprensión del presente, cuando Núñez se refiere a los tiempos de Cubagua hace énfasis en la permanencia destructora. Esa que había sido ratificada en tres niveles paralelos ya en sus

${ }^{14}$ El complejo paratexto de esta novela -como el de la coetánea Macunaíma (1928)- es canibalizado sin distingos ni jerarquías. Hay citas, referencias, paráfrasis, imágenes, extractos de libros o ideas de viajeros coloniales de diversos momentos, hasta fuentes y crónicas de indias, en particular las de Pedro de Aguado, quizás la de Benzoni y Juan de Castellanos. Asimismo aparecen alusiones a cantos de la zona, consejas e historias populares, extractos de prensa y, claro, leyendas mitológicas evocadas en todo lo referente al dios Vocchi.

15 Habrá que emprenderse no sólo la lectura comparativa de Las lanzas coloradas con Cubagua, sino, directamente, con Después de Ayacucho, que precede a ambas en once años, obra que sin duda Uslar Pietri había ya leído al momento de la escritura de su novela. Existen entre ellas muchas coincidencias y parecidos. Las aspiraciones de ascenso de sus anti-héroes, la pareja central de hermanos cuyo origen genealógico (en su construcción novelesca y referencial) los lleva hasta la Colonia, su escenario en las haciendas de Aragua, la guerra entendida como incendio, la arbitrariedad ideológica de bandos fundamentalmente vistos como conflicto de los estratos sociales bajos, etc. Intuimos, entonces, una influencia fuerte de Núñez sobre Uslar Pietri que jamás ha sido reconocida o discutida, ni por los autores ni por los críticos. Sin embargo, estas novelas se diferencian en el tono paródico de Núñez y en el apocalíptico de Uslar, así como en los puntos de vista contrarios de sus autores. Esto es claro, en particular, en cuanto a la posición metafórica que asumen frente al presente de la escritura, el de la dictadura de Juan Vicente Gómez. Núñez desmonta la factura del caudillo y la hace producto de la pérdida de valores, y allí se queda. Uslar Pietri, por su parte, insinúa la necesidad de éste ante el caos que instaura la inestabilidad de la guerra (¿el posgomecismo que comienza a prepararse ya desde 1928?).

Revista Iberoamericana, Vol. LXXVI, Núms. 232-233 Julio-Diciembre 2010,
ISSN 0034-9631 (Impreso) 
propios orígenes: el económico en el agotamiento de los placeres de perlas; el humano en la masacre de los indígenas; y el natural en el hundimiento de la Nueva Cádiz de Cubagua debido al maremoto de 1541. Así, al vincular los extremos cronológicos de la novela-actualidad ficcionalizada con historia documentada-, Núnez explicitaba el fracaso del proyecto colonial y neocolonial en la constate de una nación que no puede buscar su fundamento en sus orígenes. Igualar los dos extremos cronológicos no significaba entonces ensalzar la historia, sino hacerla patente como frustración. Cubagua no da sentido estético a una propuesta de proyecto nacional (como sí lo hace Doña Bárbara), sino que ofrece un diagnóstico trágico del destino de Venezuela, bajo las condiciones impuestas por la explotación neocolonial.

Otro aspecto peculiar de esta novela es el contraste entre una macro historia-que incluye la historia indígena, aunque no escrita-, con una suerte de historia natural, definida como hecho anterior. La naturaleza no es vista como opuesta a una cultura o civilización referencial (Gallegos como consecuencia última en Venezuela), sino como posibilidad de una historia otra, armónica, posible, intuible aunque no fácilmente descifrable. Las dos ciudades (la Nueva Cádiz de Cubagua y La Asunción, en Margarita), así como los dos momentos históricos (siglo XVI y Xx), se emplazan en una naturaleza que, de alguna manera los destruye. La naturaleza, que está vinculada a la idea del tiempo mítico, no necesaria tiene aquí un sentido exclusivamente circular, en cuanto a que en ella se inscribe una historia de apariencia lineal. Núñez aprovecha, así, este contraste y coexistencia de recurrencia y telos, como se vio en la constitución de los personajes. Desde este punto de vista, Cubagua es novela mítica sólo en cuanto "es historia descronologizada - como afirma Miliani- para imprimir permanencia a los hechos más allá del tiempo en que se produjeron. Historia y novela son dos versiones distintas de una misma realidad" (xxvi). ${ }^{16}$

Podríamos decir, entonces, que Núñez tiene un acercamiento casi animista, que cruza la ruina cultural - la ciudad presente y todo el pasado vistos como escombroscon otra historia inscrita en las costas y los paisajes, en los árboles, en las nubes, en las codiciadas perlas. Es la interrogación a los sonidos de la soledad que la destrucción ha dejado tras ella. Para entender esto, se puede comparar Cubagua con la naturaleza en Doña Bárbara, donde a través de un protagonismo arquetípico -alegórico de la nación violada que responde con violación, como plantea Liscano (xxiii)-, ésta puede ser domada y dominada mediante conocimiento, fuerza, ley y orden, superándose los conflictos de poder, para producir la metáfora fuerte de la unidad final (la de las tierras en conflicto),

16 Al mismo tiempo, esta estructura mítica funciona como recurso narrativo que, según Carrera, le permite el empleo "de la ruptura del tiempo lineal o cronológico, del recurso del paralelismo, de la simbología de la reencarnación y del proceso cíclico de la eternidad [...]" (453).

Revista Iberoamericana, Vol. LXXVI, Núms. 232-233 Julio-Diciembre 2010, $807-819$
ISSN 0034-9631 (Impreso) 
que son el espacio mismo de la nación. ${ }^{17}$ De allí, la posibilidad de mediación de Santos Luzardo, que es lo cultural-urbano-modernizador, con una Marisela transformada y una Doña Bárbara derrotada, o quizás postergada en una posibilidad resurgente (la de la barbarie dictatorial). Mientras que Doña Bárbara es magia, seducción, derecho anterior al derecho impuesto, por su sangre de indígena violada, Santos Luzardo es expresión de otro tipo de violencia, la violencia civilizatoria que se ejerce sobre el saber regional, tradicional, y que al mismo tiempo sirve como fuerza ante el poder extranjero, visto también como enemigo.

En cambio, en Cubagua, la naturaleza no es negociación, sino armonía. No encarna personajes, pero está constantemente cruzándolos, son ellos los que subjetivan el paisaje, naturalizan lo cultural. En efecto, para Núñez, la naturaleza es una suerte de historia, que forma una simbiosis con sus habitantes sucesivos. Lejos de cierta racionalidad positivista que busca imponerse en Gallegos, con las ideas de modernización, desarrollo y tecnología, en Núñez el pensamiento central es de posibilidad, potencialidad que se define en una relación mutua con la naturaleza. En este sentido, Cubagua está llena de imágenes de significado plural, a veces inestables. Los cardones son también indígenas que esperan y observan, aunque antes sus espinas habían impedido que los mismos indígenas huyeran de los españoles conquistadores y asesinos. De allí, la narración va hacia una imagen de síntesis en un supuesto presente: "(c)aminan los hombres descalzos, impasibles, taciturnos. Son hombres cardones" (56). No contento con esto, los cardones son a la vez marcas de modernidad, aparatos: "Y en realidad esas antenas podrían entregarnos el secreto de alguna teogonía inédita" (39). En el caso de Nila, ella simboliza la riqueza de la isla, es nácar, perla, pero al mismo tiempo es la selva amazónica y es referencia al barco La tirana, nombre que a su vez hace relación con el pasaje del conquistador rebelde "El tirano" Lope Aguirre, cuyos hechos son contados en la novela como si fuera una crónica periodística. ${ }^{18}$ Por su parte, las ruinas de la Nueva Cádiz de Cubagua, al mismo tiempo, son como y son la piel de Pedro Cálice, quien muere lentamente de lepra: "La espesa cabellera le sepultaba en su negrura. Toda la fisonomía de la isla estaba en aquel rostro" (22).

Es decir, en el simbolismo entreverado de las imágenes de la novela y en la construcción temporal de sus personajes, Núñez teje naturaleza y cultura en una tensión y una espera que no tienen nada de propuesta pacificadora. Si el llano gallegueano es una metáfora, Cubagua-isla es una metonimia, su historia es la historia de la nación. Si en

17 Aunque habría que matizar que en la visión gallegueana hay una naturaleza que también tiene en sí lo positivo, algo que puede resurgir de ella, en cuanto sea "manejada" por fuerzas distintas a la barbarie enseñoreada.

18 Esta supuesta crónica estaría reproducida de El Heraldo de Margarita, periódico que había sido fundado y dirigido por el mismo Núñez durante su estancia en la isla en 1925. De esta manera, el narrador estaría haciendo una referencia oblicua al autor implícito en su condición de periodista.

Revista Iberoamericana, Vol. LXXVI, Núms. 232-233 Julio-Diciembre 2010, $807-819$
ISSN 0034-9631 (Impreso) 
Doña Barbara se exige la reforma domesticadora de la naturaleza bárbara, en Cubagua se propone como rebelión. Su denuncia es la manera como se relaciona pensamiento - ¿proyecto nacional?- con geografía, expresada en una riqueza -petróleo en este caso- que, así y una vez más, se voltea en contra de sus pobladores, por la presencia de la explotación (neo)colonial. Así, el nacionalismo de Núñez se define frente a los mecanismos ideológicos de la economía internacional, representada por las empresas petroleras. Su nacionalismo es, también entonces, la propuesta de control de las riquezas, del espacio-naturaleza por sus habitantes, en la asunción imperativa de alcanzar un tiempo poscolonial, romper la fuerza de la permanencia: "Ya no son voces que se alzan del mar: murmullos, clamores vagos, estremecedores, palpitantes, infinitos. Todo estaba como hace cuatrocientos años" (66).

Para entender la visión telúrica que manejaba Núñez en los días de la novela, puede analizarse un curioso texto entre metafísico e histórico, "Una ojeada al mapa de Venezuela", escrito entre 1933 y 1934, es decir, poco después de publicada Cubagua. ${ }^{19}$ Partiendo de la premisa de una unidad espiritual primigenia de todos los pueblos, como disposición natural a interpretar y darle sentido a su entorno, el autor postula allí una fuerza recíproca entre pensamiento y naturaleza: "Porque el hombre trató siempre de reflejar la imagen del universo conforme al paisaje que le rodea, y en este caso, las ignotas llanuras y el rumor de las constelaciones en el silencio desconocido, hubieran ejercido su influencia en esa interrogación [...]” (5).

Entonces, al igual que el "secreto de la tierra" que es nombrado en la novela sin mayor explicación, este pensamiento es sólo comprensible en cuanto relación armónica con la naturaleza. La explotación - tanto colonial como neocolonial- entraba en contradicción con ella y con sus habitantes, generando desamparo en los conquistadores (como el de Leiziaga), que estaban imposibilitados de interpretarla. Con palabras, que son casi ecos de Cubagua, Núñez explica:

Pero hay el silencio y la soledad. Existen las serranías sobrepasándose siempre, y los horizontes. En todo esto hay imágenes. Se cree percibir cosas que existen o han existido. Algo que escapa a nuestros sentidos. En fin, eso que los conquistadores, cuando sentían turbada su alma en medio de las soledades, llamaban el secreto de la tierra. [...] Así, ese contorno que contemplamos nos ofrece algo más que los simples relieves de su aspecto físico y nos encontramos frente a una inteligencia; un pensamiento abandonado a la tierra. $(4-5)^{20}$

19 Sorprende que la mayoría de los críticos que han abordado la novela no hayan prestado suficiente atención a este ensayo, favoreciendo el más directo y posterior "Discurso ante la Academia de la Historia", de 1948.

${ }^{20}$ Ideas casi idénticas llenan la novela, como cuando Leiziaga piensa: “...los campos donde flota un aire de cosas inmemoriales y extinguidas [...] En la espuma como en la niebla y el silencio hay imágenes

Revista Iberoamericana, Vol. LXXVI, Núms. 232-233 Julio-Diciembre 2010, $807-819$
ISSN 0034-9631 (Impreso) 
Esta interrogación a lo inanimado estaba sostenida sobre una elaboración pitagórica del mundo como orden (a través del Timeo de Platón), que establece relaciones entre espíritu, cuerpo y cosmos, armonía universal inteligible sólo a través del número. El paisaje se torna identidad que va más allá de lo histórico y lo historiado (oral o escrito), pero cuyo sentido se forma a lo largo de las sucesivas sociedades que la habitan e interpelan, en este caso, comenzando por la de los indígenas, entendidos como habitantes primigenios que no pudieron alcanzar su plenitud creativa debido a la irrupción violenta conquistadora. La escasez de documentos, apenas restos arqueológicos, dice Núñez, una señal escrita en piedra, una melodía, una leyenda -es decir, un archivo como el empleado en la escritura de Cubagua-, no es óbice para intuir la potencialidad que se cifra en el entorno, y representar desde allí el universo.

Entonces, lo indígena en Cubagua, más que una referencia específica a las escasas etnias sobrevivientes en Venezuela, era la fuerza que surge de una deuda pendiente, preguntas que quedan como silencios llenos de significados. En su siguiente novela, La galera de Tiberio (escrita entre 1931 y 1932), que de manera directa da continuidad a preocupaciones equivalentes, el narrador dice: "El silencio del indio era un estado de alma. Un estado de alma que duraba siglos" (54). Así, no hay un uso indigenista ni una mera evocación retórica, como tampoco una vuelta idílica al pasado, sino que se presenta lo indígena como conciencia pendiente de una civilización que quedó incompleta. Tampoco es, entonces como ya vimos, una mera indagación histórica, sino en todo caso, una crítica de ésta como parte de la ideología imperante que obliga a su aceptación como factum, como condicionante inapelable. En efecto, el énfasis de la ficción novelesca de Cubagua busca demostrar el presente de las fuerzas conservadoras de la permanencia, por cierto, hecho que lo acerca a su coetáneo Mariátegui. Núñez afirma en Una ojeada:

La tierra y el tiempo. Porque no es en un pasado definitivamente muerto donde será posible encontrar el ritmo acelerado de esa actividad creadora. [...] La cultura en todo caso, no es inercia o inmovilidad de espíritu. No es una expresión arcaica. Es, ante todo, comprensión y facultad de proseguir la historia. Y no es que se quiera hacer profesión de fe contra el pasado. Aquí mismo hemos visto cómo en sus entrañas pueden hallarse los augurios del presente y del futuro. Hay fuentes recientes ya exhaustas y en cambio otras de origen remoto que fluyen siempre jóvenes. Sin duda el pasado puede ofrecernos un refugio donde palpar el color ideal y fastuoso de las cosas antiguas. Pero un culto

fugitivas. Son tan ligeras en su eternidad que apenas podemos sorprenderlas; pero en ocasiones, un sonido, una palabra u otro accidente inesperado, provoca la revelación maravillosa en el hondo misterio de las costas y serranías" (17). O cuando fray Dionisio pregunta: “Has comprendido, Leiziaga, todo lo que ha pasado aquí? ¿Interpretas ahora este silencio?" (38) Y, cuando el mismo cura le dice que las espinas del cardón eran "antenas (que) podrían entregarnos el secreto de alguna teogonía inédita [...] O quizás pertenece a los signos de algún zodíaco perdido" (39).

Revista Iberoamericana, Vol. LXXVI, Núms. 232-233 Julio-Diciembre 2010, $807-819$
ISSN 0034-9631 (Impreso) 
exclusivo del pasado supone no ya un retorno estéril sino una superchería -y todavía más- la atrofia del cuerpo y del espíritu. (21, énfasis nuestro)

Lo indígena aquí también ronda una referencialidad antiimperialista continental, ${ }^{21}$ funcionando, una vez más en nuestra historia cultural, como apelativo a un todo originario, más que propiamente étnico o cultural (aunque sin negarlo). En el personaje de Nila Cálice, que expresa las múltiples versiones de la posibilidad indígena, se personifica la idea de la resistencia y la rebeldía ante la presión de la modernidad internacionalizada, travestida en nuevas prebendas económicas y sociales para las clases hegemónicas y para los países centrales, y en nuevas formas de sometimiento. Lo indígena representa, entonces, la fuerza de lo propio, de lo auténtico, es la potencialidad de la narración y de la nación, a la que hay que apelar y comprender con sentido descolonizador. ${ }^{22}$

Concluyendo, Cubagua expresa una tensión entre una peculiar visión metafísica y novelesca, que utiliza un amplio archivo con sentido contrahegemónico, en dirección a un cuestionamiento del proyecto nacional (reformista o populista) que se proponía en el nuevo estampado de las relaciones internacionales de finales de los años veinte, nuevo orden en el que Venezuela, de manera tan medular, se inscribía como uno de los principales productores de energía en el mundo. Sólo desde ahí se entiende que Núñez postule la naturaleza como recurso efectivo para criticar las continuidades entre pasado y presente, continuidad de las clases enseñoreadas de la historia y de su fracaso. La colonia implanta una economía ineficiente basada en la destrucción y en la separación de la naturaleza, que aún permanecía durante el período central del gomecismo, como economía neocolonial, para miseria de los pueblos que aún la sufrían. Interrogación cuestionadora y crítica desde sus bases históricas, pero también desde las alternativas ideológicas y económicas que entonces se planteaban. "El mar es comunista" (54), dice en algún momento el narrador, más como constatación que como propuesta. Así, Cubagua es una mirada no nostálgica sino cuestionadora a ese pasado, para apoyarse en la potencialidad territorial y social de Venezuela (o de Latinoamérica, como quiere

${ }^{21}$ Hay un apelar reiterado a lo indígena en algunos de los escritores y artistas más interesantes de esta generación en Venezuela, lo que permite pensar en referencias que pudieran conformar símbolos de "autenticidad" frente al tono extranjerizante de los representantes internos del imperialismo en ascenso, que se vive cada vez más en la cotidianidad del país, como expresión cultural de la explotación petrolera en crecimiento. Ejemplos de esto lo encontramos en Áspero (1924), de Antonio Arráiz, en el libro Poemas de la musa libre (1928), de Ismael Urdaneta, incluso en el poema de Luis Castro aparecido en la única revista "vanguardista" venezolana, válvula (1928).

${ }^{22}$ Se puede contrastar esto con la decadencia y debilidad que lo indígena representa (como lo negro y todo lo no-blanco del componente mestizo) en Las lanzas coloradas. La exaltación del mestizo, aparentemente, sobre el criollo tiene un tinte casi populista -muy distinto, claro está, del de Gallegos-, fundando la imposibilidad del cambio y, de allí, la necesidad de liderazgo, Bolívar, el criollo inferido y esperado pero no presente. En realidad, el pasado ideal de Las lanzas coloradas está puesto en los encomenderos previos a la perdición que produce la aspiración de alcanzar El Dorado.

ISSN 0034-9631 (Impreso) 
Miliani), la de sus recursos económicos naturales, y las de las fuerzas populares reformuladas en su relación con la historia, con lo que la novela cobra un fundamento político-literario, no sólo novedoso, sino todavía inquietante y actual.

\section{BibliografíA}

Araujo, Orlando. "Ensayo sobre la obra literaria de Enrique Bernardo Núñez". E. B. Núñez. Cacao. Caracas: Banco Central de Venezuela, 1972. 21-103.

Benzoni, Girolamo. Historia del Nuevo Mundo. M. Carrera Díaz, trad. Madrid: Alianza, 1989.

Betancourt, Rómulo. “Apuntes para una interpretación de Doña Bárbara”. Repertorio Americano (4.10.1930): 201-2.

Beverley, John. "Novela y política en América Latina (De Doña Bárbara a Cien años de soledad)". Del Lazarillo al sandinismo: Estudios sobre la función ideológica de la literatura española e hispanoamericana. Minneapolis: Institute for the Study of Ideologies and Literature, 1987. 99-122.

Britto García, Luis. "Enrique Bernardo Núñez, novelista, historiador, filósofo de la historia utopista". Memorias del XXIII Simposio de Docentes e Investigadores de la Literatura Venezolana: Trujillo, del 19 al 22 de noviembre de 1997. Trujillo: Universidad de los Andes, 1998. 645-68.

Carrera, Gustavo Luis. "Cubagua y la fundación de la novela venezolana estéticamente contemporánea”. Revista Iberoamericana LX/166-167 (1994): 451-56.

Gallegos, Rómulo. Doña Bárbara. Caracas: Biblioteca Ayacucho, 1977.

Larrázabal Henríquez, Osvaldo. Enrique Bernardo Núñez. Caracas: Universidad Central de Venezuela, 1969.

Liscano, Juan. "Prólogo". Rómulo Gallegos. Doña Bárbara. Caracas: Biblioteca Ayacucho, 1977. IX-XXIX.

Miliani, Domingo. Introducción. Enrique Bernardo Núñez. Cubagua. La galera de Tiberio. La Habana: Casa de las Américas, 1978. VII-XLV.

Núñez, Enrique Bernardo. Después de Ayacucho. Caracas: Biblioteca Venezuela de El Universal, 1920.

"Discurso de incorporación a la Academia de la Historia: La historia de Venezuela". (Caracas, 1948). Una ojeada al mapa de Venezuela. $2^{\mathrm{da}}$ ed. Caracas: Ávila gráfica, 1949. 209-38.

Don Pablos en América. (Tres relatos). Caracas: Élite, 1932.

La galera de Tiberio. (Crónica del Canal de Panamá). Bélgica: s.e., (c. 1938) Novelas y ensayos. O. Larrazábal, ed. Caracas: Biblioteca Ayacucho, 1987. Sol interior. Caracas: Tipografía Americana, 1918. Una ojeada al mapa de Venezuela. Caracas: Ávila gráfica, 1949.

Revista Iberoamericana, Vol. LXXVI, Núms. 232-233 Julio-Diciembre 2010, $807-819$
ISSN 0034-9631 (Impreso) 
Pacheco, Carlos. "Cubagua: El ojo de la ficción penetra la historia". Folios (octubre 1999): 35-6.

Uslar Pietri, Arturo. Letras y hombres de Venezuela. México: FCE, 1948.

Vilanova, Ángel. "Para una lectura crítica de Cubagua". Escritura XVIII, 16 (juliodiciembre, 1983): 233-250.

Revista Iberoamericana, Vol. LXXVI, Núms. 232-233 Julio-Diciembre 2010, 807-819 ISSN 0034-9631 (Impreso) ISSN 2154-4794 (Electrónico) 
